\title{
Fenomena Urbanisasi: Transformasi Spasial di Kawasan Pinggiran Kabupaten Sidoarjo
}

\author{
Urbanization Phenomenon: Spatial Transformation in Sub-urban area, \\ Sidoarjo Regency.
}

\section{Siti Nuurlaily Rukmana ${ }^{1}$, Moch.Shofwan ${ }^{1}$}

Diterima: 22 April 2019

Disetujui: 1 April 2020

\begin{abstract}
Abstrak: Fenomena transformasi perkotaan juga terjadi di Kabupaten Sidoarjo yang secara administrasi terletak di sekitar Kota Surabaya. Buktinya yaitu terjadinya perluasan lahan terbangun di beberapa kecamatan seperti di Kecamatan Krian. Tujuan Penelitian ini adalah menganalisis transformasi spasial dilihat dari alih fungsi lahan dan mengevaluasi presentase pemanfaatan lahan yang telah sesuai dengan kebijakan dokumen tata ruang. Teknik analisis yang digunakan yaitu menggunakan teknik Geograpical Information System dan Remote Sensing, kemudian dilanjutkan dengan deskriptif evaluatif. Hasil dari penelitian ini bahwa tranformasi lahan terbangun sejak tahun 1995-2018 yaitu 5,23\% sedangkan yang tidak sesuai dengan dokumen tata ruang sebesar 7,63\%.
\end{abstract}

Keyword in Bahasa: Geograpical Information System, Perubahan lahan, Remote Sensing, Urbanisasi

\begin{abstract}
The phenomenon of urban transformation also occurs in Sidoarjo Regency which is located around the city of Surabaya. Its evidence is the expansion of built up area in several districts like Krian district. The aims of this resech are analyzing the spatial transformation in term of land use change and evaluating the percentage of land use that it is accordance with spatial document policy. The analysis technique use Geogrphical Information System and Remote Sensing then proceed with descriptive evaluative. The result of this research can be seen that the transformation of built up area since 1995-2018 is 5,23\% while those that are not accordance with spatial documen are $7,63 \%$.
\end{abstract}

Keywords: Geograpical Information System, Land use change, Urbanization, Remote Sensing

\section{PENDAHULUAN}

Pada satu dekade ini penelitian terkait dengan permasalahan perkotaan telah menjadi topik penting dalam dunia perencana. Topik ini menekankan pada fenomena transformasi perkotaan ke kawasan pinggiran, yang sering disebut sebagai urbanisasi. Urbanisasi terjadi disebabkan tidak seimbangnya antara ketersediaan lahan dan jumlah penduduk. Hal ini disebabkan adanya pemusatan aktivitas di perkotaan sehingga menyebabkan angka permintaan lahan menjadi tinggi salah satunya untuk kegiatan permukiman (Samat, 2011; Arta \& Pigawati, 2015; Ives \& Kendal, 2013; Paül \& McKenzie, 2013; Shi, Sun, Zhu, Li, \& Mei, 2012). Dampak dari permintaan kebutuhan lahan permukiman ini yaitu perluasan kawasan ke daerah pinggiran kota. Daerah

\footnotetext{
${ }^{1}$ Departemen Perencanaan Wilayah dan Kota Universitas PGRI Adi Buana Surabaya
} 
pinggiran kota juga menjanjikan harga dan jarak yang terjangkau bagi masyarakat. Namun efek dari fenomena ini yaitu adanya transformasi kekotaan di sekitar daerah pinggiran.

Fenomena transformasi perkotaan merupakan salah satu gejala yang berkaitan dengan demografi . Perkembangan demografi ini menjadi sebuah bukti bahwa kota itu dinamis. Pernyataan ini juga selaras dengan (Simon, 2008); (Aguilar, 2008) bahwa perkembangan demografi menyebabkan adanya perluasan perkotaan di kawasan sekitarnya. "Salah satu bukti terjadinya perluasan perkotaan yaitu adanya perubahan lahan (Rukmana \& Rudiarto, 2016), (Manaugh, Badami, \& El-geneidy, 2015) dan berkembanganya lahan terbangun (Xiao, Shen, Ge, Tateishi, \& Tang, 2006)". Selain dari tingginya angka demografi yang menyebabkan terjadinya tranformasi perkotaan di kawasan pinggiran juga disebabkan karena jaringan infrastruktur (Prawatya, 2013) yang strategis. Hal ini terbukti secara administrasi bahwa keberadaan kawasan pinggiran cukup strategis seperti akses yang terjangkau dengan pusat kota dan SDA yang masih lebih baik daripada di pusat kota.

Kabupaten Sidoarjo merupakan salah satu daerah yang berbatasan dengan Kota Surabaya dan telah mengalami proses urbanisasi. Hal ini selaras dengan aktifitas kegiatan yang tertuang dalam RTRW Provinsi Jawa Timur tahun 2019 bahwa "wilayah inti Gerbangkertasusila Plus (Surabaya, sebagian Gresik, sebagian Sidoarjo dan sebagian Bangkalan) memiliki kegiatan aktivitas yang di dominasi oleh industry, perdagangan dan jasa serta pemerintahan Regional Jawa Timur". Guna mengurangi ketimpangan wilayah, maka dibutuhkan sebuah koneksi yaitu pengembangan jalan tol di Kabupaten Sidoarjo. Dampak dari fenomena tersebut yaitu terlihat pada perubahan struktur dan pola ruang salah satunya yaitu menjalarnya lahan terbangun khusunya di sekitar kawasan perdesaan Kabupaten Sidoarjo. Berdasarkan data diketahui bahwa alih fungsi lahan pertanian di Kabupaten Sidoarjo sejak 2009-2015 yaitu 23,539 Ha menjadi 19,544 Ha. Sehingga dapat di definisikan pada rentan waktu 5 tahun lahan di Kabupaten Sidoarjo telah mengalami penyusutan sekitar 4,995 Ha (Karim, 2016). Selain itu menurut penelitian sebelumnya (Rukmana \& Widyastuti, 2018) bahwa daerah pingiran di Kabupaten Sidoarjo terdiri dari 5 kecamatan yaitu Kecamatan Krian, Kecamatan Candi, Kecamatan Krembung, Kecamatan Tanggulangin dan Kecamatan Sukodono. Oleh karena itu fokus dari penelitian ini adalah transformasi spasial dan mengevaluasi presentase pemanfaatan lahan yang sesuai dengan kebijakan penataan ruang .

\section{METODE}

Wilayah studi penelitian ini yaitu di kawasan pinggiran Kabupaten Sidoarjo (Gambar 1). Pada penelitian ini menggunakan pendekatan deskriptif kuantitatif. Biasanya pendekatan kuantitatif melibatkan dimulai dari tahap pengumpulan data, analisis, interpretasi dan dilanjutkan pada penuliasan hasil-hasil penelitian (Creswell, 2009).

Teknik penelitian ini yaitu (1) Menganalisis transformasi spasial kawasan pinggiran di lihat dari alih fungsi lahan yaitu menggunakan remote sensing dan penginderaan jauh. Lillesand dan Kiefer (1979) mendefinisikan Penginderaan jauh (remote sensing) sebagai bidang keilmuan dan ketrampilan untuk memperoleh informasi tentang obyek, daerah, atau fenomena melalui analisis data yang diperoleh dengan suatu alat tanpa kontak langsung dengan obyek, daerah, atau fenomena yang dikaji. Hasil dari perhitungan tersebut maka dilanjutkan dengan (2) mengevaluasi presentase pemanfaatan lahan yang telah sesuai dengan kebijakan dokumen tata ruang. Guna tercapainya tujuan dari penelitian ini maka metode pengumpulan data pada penelitian ini mneggunakan data primer berupa observasi dan wawancara serta data sekunder. 


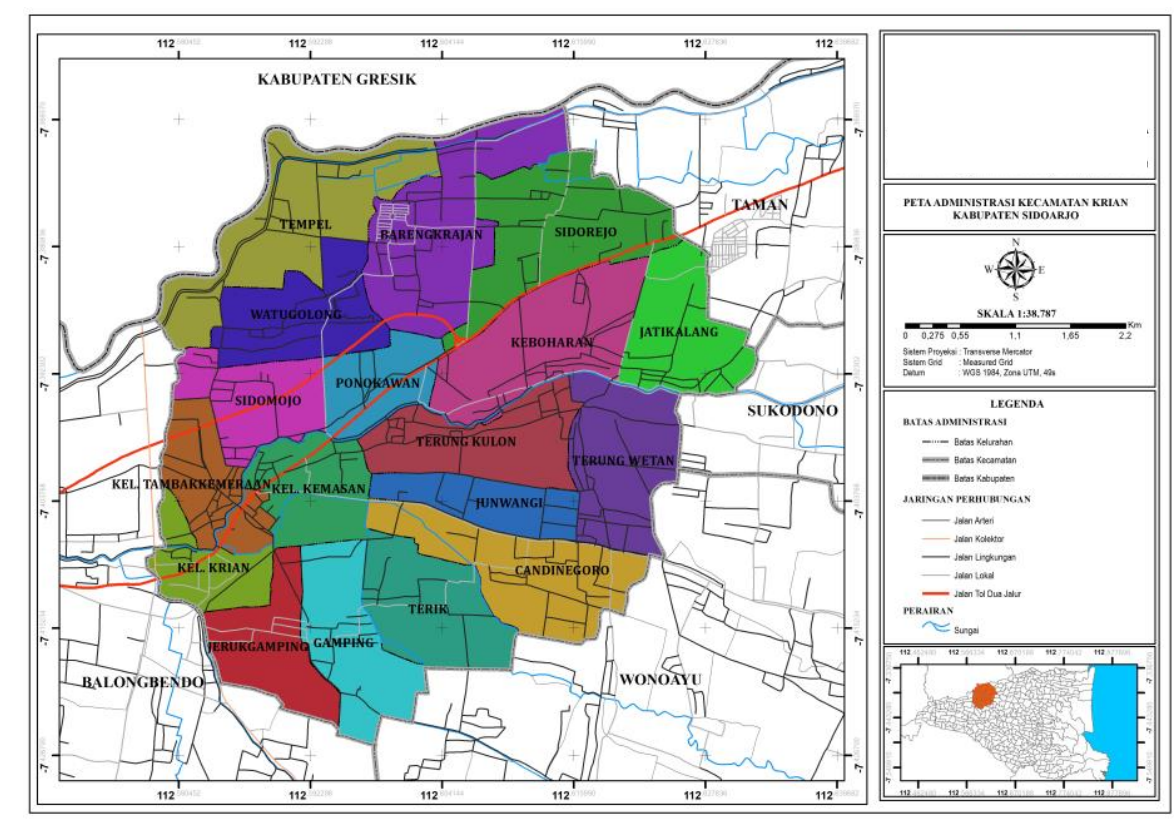

Gambar 1. Wilayah Studi Penelitian

\section{HASIL DAN PEMBAHASAN}

Keberadaan pengembangan jalan tol di Kabupaten Sidoarjo ternyata memiliki pengaruh bagi wajah kota khususnya jika dilihat dari segi fisiknya. Keberadaan tol ini mempermudah masyarakat dalam melakukan pergerakan ke daerah sekitarnya, seperti Sidoarjo-Surabaya dan Sidoarjo-Gresik. Fenomena ini tentunya akan memicu terjadinya perubahan struktur dan pola ruang salah satunya yaitu menjalarnya lahan terbangun khusunya di sekitar kawasan perdesaan Kabupaten Sidoarjo. Penelitian ini fokus di Kecamatan Krian dimana lokasi penelitian merupakan salah satu Kawasan Pinggiran di Kabupaten Sidoarjo ( Rukmana \& Widyastuti, 2018)

\section{Transformasi Lahan Terbangun}

"Yunus (2008) menyampaikan bahwa "transformasi spasial merupakan artikulasi dari kegiatan manusia yang ada di muka bumi ini". Terdapat beberapa indikator untuk mengukur tranformasi spasial seperti: "bentuk pemanfaatan lahan, harga lahan, jumla dan kepadatan penduduk, karakteristik permukiman, karakteristik bangunan serta aksesbilitas". Pada penelitian ini transformasi spasial hanya focus pada perubahan lahan pertanian dimulai tahun 1995, 2008, 2018. Proses analisis yang dilakukan yaitu dengan analisis citra landsat yang kemudian dicocokkan dengan kondisi eksisting sehingga mengurangi tingkat kesalahan pada hasil perubahan lahan tersebut. Berikut dapat dilihat proses analisis citra landsat di (Gambar 2). Proses analisi yang digunakan Untuk mengetahui perkembangan luasan area lahan terbangun dan tidak terbangun di Kecamatan Krian. digunakan pendekatan analisis pengindraan jauh melalui Citra Landsat TM 7 mulai dari tahun 1995, 2005, dan 2015. Pengambilan data citra untuk proses gap and fill berasal dari citra dengan path 118 row 65 dengan tanggal akusisi :

a) Citra Tahun 1995 : Tanggal akusisi yakni 24 Mei 1995 dan 27 Juli 1995

b) Citra Tahun 2008 : Tanggal akusisi yakni 4 Februari 2008, 8 Maret 2008, 16 September 2008 dan 2 Oktober 2008;

c) Citra Tahun 2018 : Tanggal akusisi yakni 7 Mei 2018, 26 Juli 2018, dan 30 Oktober 2018. 

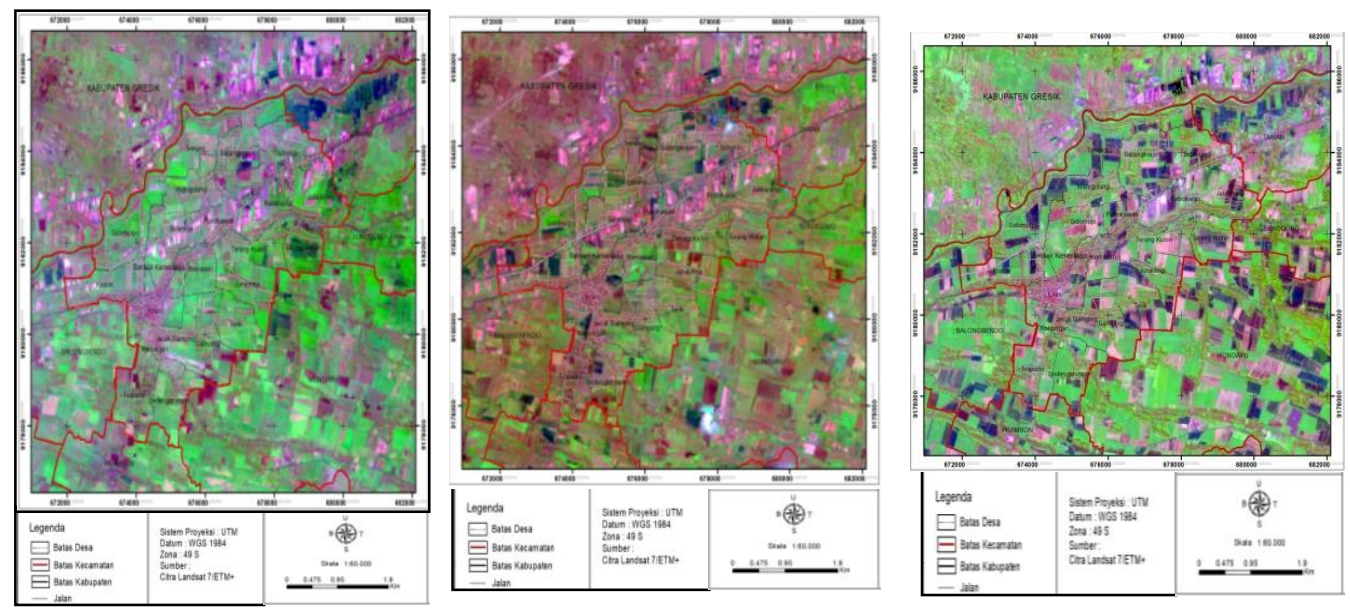

Sumber: Hasil Analisa, 2018

\section{Gambar 1. Peta Analisis Citra Landsat melalui Remote Sensing Tahun 1995, 2008, 2018 di Kecamatan Krian}

Kemudian data citra Landsat 7/ETM + terlebih dahulu dilakukan cropping untuk masing-masing rekaman tahun di wilayah penelitian yaitu Kecamatan Krian. Selanjutnya dilakukan proses pemulihan citra melalui koreksi geometrik dan radiometrik. Hasil klasifikasi tersebut selanjutnya dilakukan editing untuk kebenaran dengan data lapangan. Tutupan lahan yang diidentifikasi dari citra dibagi menjadi 2 (dua) jenis tutupan lahan yakni lahan terbangun dan lahan tak terbangun. Hasil klasifikasi citra Landsat 7/ETM+ menunjukkan perubahan penutupan lahan di wilayah penelitian (table 1) dan (Gambar 3):

Tabel 1. Transformasi Lahan terbangun di Kecamatan Krian

\begin{tabular}{|c|c|c|c|c|c|c|}
\hline \multirow{2}{*}{ Jenis } & \multicolumn{2}{|c|}{ Tahun 1995} & \multicolumn{2}{|c|}{ Tahun 2008} & \multicolumn{2}{|c|}{ Tahun 2018} \\
\hline & Luas $(\mathrm{Ha})$ & Persentase & Luas (Ha) & Persentase & Luas (Ha) & Persentase \\
\hline $\begin{array}{l}\text { Lahan } \\
\text { terbangun } \\
\text { Lahan }\end{array}$ & 2430,95 & 75,03 & 2253,68 & 69,56 & 1923,42 & 59,36 \\
\hline terbangun & 809,17 & 24,97 & 986,43 & 30,44 & 1316,70 & 40,64 \\
\hline Jumlah & 3240,11 & 100,00 & 3240,11 & 100,00 & 3240,11 & 100,00 \\
\hline
\end{tabular}

Sumber: Hasil Analisa, 2018

Berdasarkan hasil analisis, maka dapat disimpulkan:

1. Lahan terbangun di Kecamatan Krian mengalami expansi ke arah timur sedangkan arah barat perkembangan lahan terbangun semakin luas (padat);

2. Lahan tidak terbangun (fokus pada pertanian) mengalami penurunan di tahun 2008 sampai tahun 2018;

3. Kawasan permukiman di Kecamatan Krian secara periodik mengalami pertumbuhan di tahun 2008 dan 2018 dikarenakan laju pertumbuhan penduduk sangat signifikan di tiap tahunnya, terlebih setelah tahun 2006 keatas (yang ditandai dengan adanya kejadian luapan lumpur Lapindo) sehingga pola ruang Kabupaten Sidoarjo secara otomatis mengarah kearah barat khususnya di wilayah Kecamatan Krian;

4. Akibat adanya perubahan pola ruang kawasan pertanian menjadi kawasan terbangun (permukiman), maka secara otomatis kawasan perdagangan dan jasa juga terus mengalami kenaikan di tahun; 
5. Ketika segala aspek pendukung kemajuan ekonomi terdapat di kawasan Kecamatan Krian, maka Sektor Industri juga mulai muncul di tahun 2005 dan semakin tumbuh di tahun 2015. Hal ini juga disampaikan oleh (Xiao et al., 2006)bahwa keberadaan sektor industri memiliki pengaruh yang tinggi terhadap terjadinya perubahan lahan.

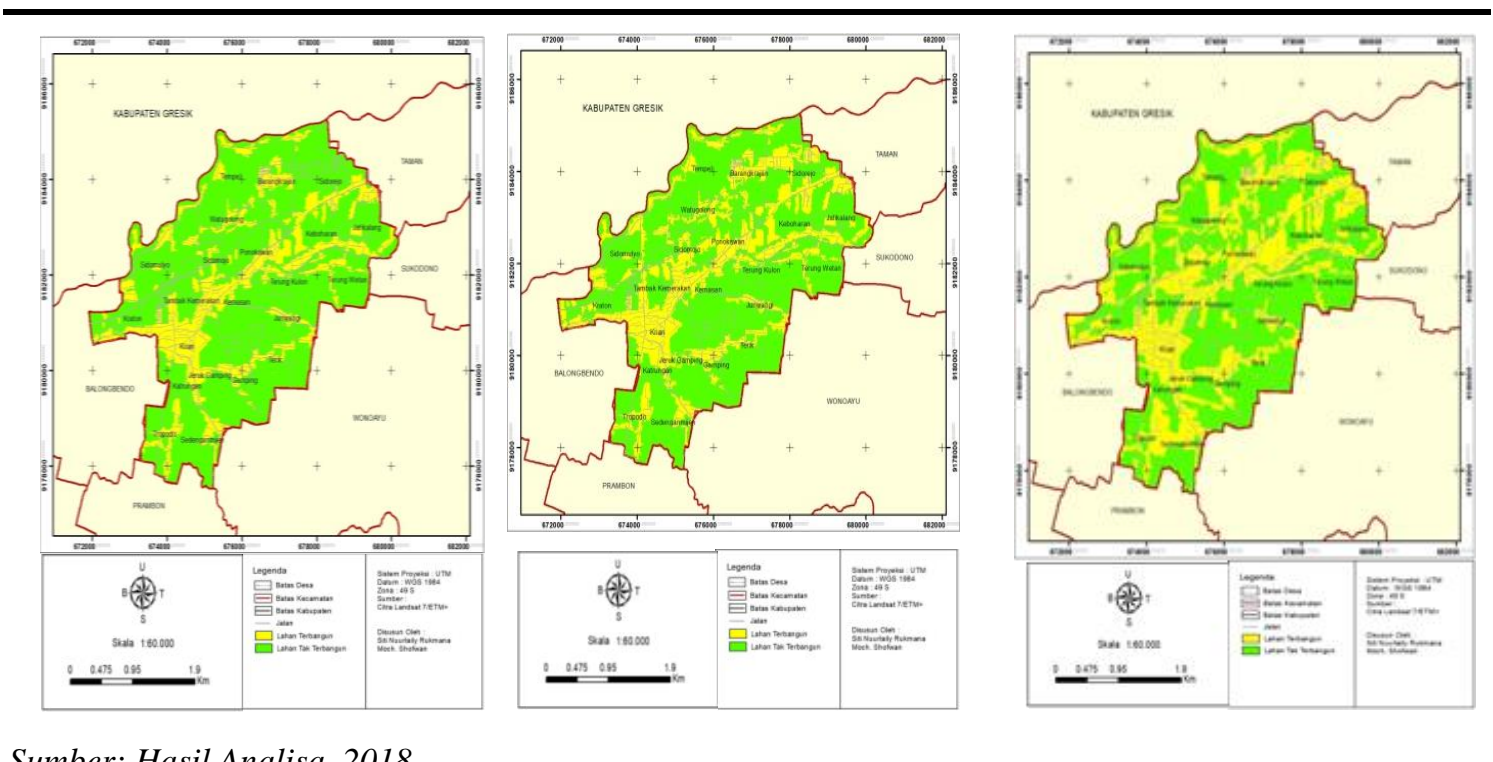

Sumber: Hasil Analisa, 2018

Gambar 2. Peta Transformasi Lahan Tahun 1995, 2008, 2018

\section{Presentase Pemanfaatan Lahan}

Pemanfaatan lahan pada penelitian fokus pada membandingkan antara hasil analisis citra landsat yang digunakan sebagai dasar kondisi lahan saat ini dengan kebijakan tata ruang. Teknik yang digunakan pada penelitian ini yaitu overlay. Berikut hasil analisis pemanfaatan lahan yang di dasarkan pada peta tutupan lahan (Gambar 3), maka diperoleh prosentase sesuai dan tidak sesuai pemanfaatan ruang di Kecamatan Krian (Gambar 4).

Sehingga berdasarkan hasil analisis bahwa pemanfaatan lahan yang tidak sesuai dengan kebijakan penataan ruang di Kecamatan Krian sebesar 7,63\% dari total tata guna lahan yang ada di Kecamatan Krian. Ditambahkan pada penelitian sebelumnya (Yunanto \& Susetyo, 2018) yang menyebutkan bahwa keberadaan Tol Krian memiliki dampak pada perubahan lahan baik di krian maupun di kecamatan driyorejo-Gresik (sebagai kawasan yang berbatasan dengan Kecamatan Krian-Sidoarjo dan Kecamatan Driyorejo-Gresik). Perubahan lahan hanya focus pada " 2 jenis lahan tidak terbangun yaitu lahan pertanian yang berpotensi berubah sebesar 307,29 Ha dan lahan RTH yang berpotensi untuk berubah sebesar 34,9 Ha". Kaitannya dengan pembangunan koridor timur (meliputi Kecamatan Buduran, Kecamatan Sidoarjo, Kecamatan Candi) Kabupaten Sidoarjo yang memiliki linkage dengan jalur lingkar timur dapat diketahui bahwa ada korelasi positif antara pembangunan di koridor barat (meliputi Kecamatan Sidoarjo Barat, Kecamatan Tulangan, Kecamatan Krian) dan koridor timur yang ditunjukkan dalam RPJM dan RPJP kabupaten. Berdasarkan dokumen tersebut dapat dijabarkan bahwa pembangunan koridor timur diarahkan untuk kawasan industri, sedangkan koridor barat diarahkan sebagai kawasan permukiman dan pertanian. Hal ini juga dituliskan dalam penelitian sebelumnya (Ajimas \& Ariastita, 2017) bahwa perubahan lahan yang tidak sesuai dengan penataan ruang khususnya di koridor lingkar timur Sidoarjo dengan kategori perubahan "cepat" adalah 
lahan pertanian menjadi pergudangan $(5,9 \mathrm{Ha} /$ tahun $)$ dan pertanian menjadi fasilitas umum (6,3 Ha/tahun).
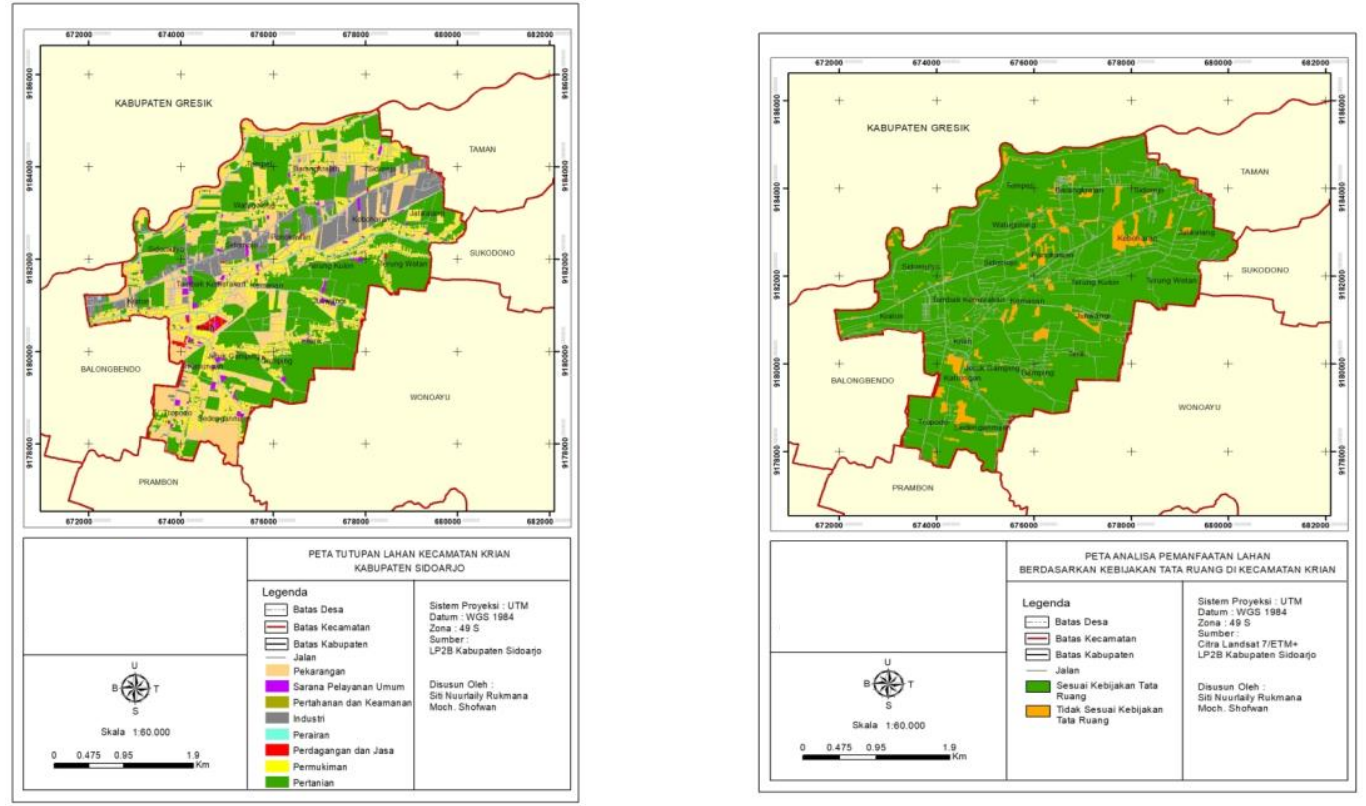

Sumber. Hasil Analisis, 2018

\section{Gambar 3. Peta Tutupan Lahan Kecamatan Krian (kiri) Peta Pemanfaatan Lahan Berdasarkan Tata Ruang (kanan)}

\section{KESIMPULAN}

Terjadinya pertumbuhan baru di Kecamatan Krian berdampak adanya tranformasi spasial seperti secara fisik. Salah satunya tranformasi lahan telah mengalami expansi ke arah timur sedangkan arah barat perkembangan lahan terbangun semakin padat. Sehingga adanya transformasi spasial tersebut berpengaruh pada perubahan pemanfaatan lahan. Terdapat 7,63\% pemanfaatan lahan yang tidak sesuai dengan kebijakan penataan ruang.

\section{PERNYATAAN RESMI}

Terima kasih kepada Kemenristekdikti yang telah mendukung penelitian ini di Skim PDP DIKTI Tahun Anggaran 2018 dan masyarakat yang ada di wilayah studi yang telah memberikan informasinya.

\section{DAFTAR PUSTAKA}

Anonim, 2009. Rencana Tata Ruang Wilayah Provinsi Jawa Timur Tahun 2009-2029.

Aguilar, A. G. (2008). Peri-urbanization, illegal settlements and environmental impact in Mexico City. Cities, 25(3), 133-145. https://doi.org/10.1016/j.cities.2008.02.003

Ajimas, K. W., \& Ariastita, P. G. (2017). Karakteristik Perubahan Penggunaan Lahan yang Tidak Sesuai Rencana Tata Ruang Di Koridor Lingkar Timur Sidoarjo. Jurnal Teknik ITS, 6(1), 1-3. https://doi.org/10.12962/j23373539.v6i1.22341

Manaugh, K., Badami, M. G., \& El-geneidy, A. M. (2015). Integrating social equity into urban transportation planning: A critical evaluation of equity objectives and measures in transportation plans in North America. Transport Policy, 37, 167-176. https://doi.org/10.1016/j.tranpol.2014.09.013

Prawatya, N. A. (2013). Perkembangan Spasial Kota-Kota Kecil Di Jawa Tengah. Jurnal Wilayah Dan Lingkungan, 1(April), 17-32. 
Rukmana, S. N., \& Rudiarto, I. (2016). Land Use Change In Suburban Area: A Case of Malang City, East Java Province. Geoplanning, 3(1), 23-32. https://doi.org/10.14710/geoplanning.3.1.23-32

Rukmana, S. N., \& Widyastuti, A. A. S. A. (2018). Towards sustainable development: resource approach through interaction of peri-urban and surrounding areas Towards sustainable development: resource approach through interaction of peri-urban and surrounding areas. Earth and Environmental Science, 12058. https://doi.org/10.1088/1755-1315/202/1/012058

Rukmana, S. N., \& Widyastuti, A. A. S. A. (2018). Towards sustainable development: resource approach through interaction of peri-urban and surrounding areas Towards sustainable development : resource approach through interaction of peri-urban and surrounding areas. Multi Perspectives on Peri-Urban Dynamics Towards Sustainable Developmen. https://doi.org/10.1088/1755-1315/202/1/012058

Samat, N. (2011). Modelling Land Use Changes at the Peri-Urban Areas Using Geographic Information Systems and Cellular Automata Model. 4(6), 72-84. https://doi.org/10.5539/jsd.v4n6p72

Simon, D. (2008). Urban Environments: Issues on the Peri-Urban Fringe. https://doi.org/10.1146/annurev.environ.33.021407.093240

Xiao, J., Shen, Y., Ge, J., Tateishi, R., \& Tang, C. (2006). Evaluating urban expansion and land use change in Shijiazhuang, China, by using GIS and remote sensing. 75, 69-80. https://doi.org/10.1016/j.landurbplan.2004.12.005

Yunanto, M. A., \& Susetyo, C. (2018). Prediksi Perubahan Penggunaan Lahan Akibat Pembangunan Gerbang TOL Krian dan Driyorejo di Kecamatan Driyorejo. Jurnal Teknik ITS, 7(2). https://doi.org/10.12962/j23373539.v7i2.33475

Yunus, H. 2008. Dinamika Wilayah Peri-Urban (Determinan Masa Depan Kota).Pustaka Pelajar : Yogyakarta 